\title{
The Future of the International Law of Capture Fisheries
}

\author{
Mary Beth West \\ Deputy Assistant Secretary for Oceans and Space, U.S. Department of State \\ 2201 C Street N.W., Washington, D.C., USA 20520
}

\begin{abstract}
The future of the international law of capture fisheries must have as its continued foundation the 1982 United Nations Convention on the Law of the Sea. However, a new environmental awareness and a more specific articulation of legal responsibilities in international fisheries conservation and management are reflected by the recent adoption of the UN Agreement on Straddling Fish Stocks and Highly Migratory Fish Stocks and the Agreement to Promote Compliance with International Conservation and Management Measures by Fishing Vessels on the High Seas. These Agreements, plus the Code of Conduct for Responsible Fisheries, contain a number of provisions that reflect environmental goals that are both broader and more specific. These goals include the need for consideration of aquatic ecosystems, the need for an ecosystem approach to management, and the need to minimize by-catch, pollution, waste and discards. As such, they illustrate what is essentially a "paradigm shift" in international fisheries, which flows from the increasing nexus between international fisheries law and international environmental law. This paradigm shift involves growing recognition of the requirement for ecosystem concerns and steps to protect fisheries habitat for the sustainable conservation and management of capture fisheries. In response to this paradigm shift, regional fisheries organizations like NAFO must incorporate an ecosystem perspective in their work if they are to remain relevant in the next century.
\end{abstract}

Key words: capture fisheries, environment, International agreements, management

\section{Introduction}

In the celebrated epic of undersea discovery, Twenty Thousand Leagues under the Sea, Jules Verne described the Atlantic Ocean as a "magnificent field of water, incessantly ploughed by vessels of every nation." These words fittingly describe the diversity of nations whose fishing vessels have for centuries visited the Grand Banks and the fishing grounds of the Northwest Atlantic. The legacy of nearly 500 years of international fishing activities in the Northwest Atlantic Ocean is reflected not only in text books, but also in the names of towns, headlands and bays throughout Newfoundland, Labrador and neighboring areas, which can be traced to English, French, Breton, Spanish, Basque and Portuguese origins.

As a North Atlantic fishing nation, the United States shares with Newfoundland and Labrador a long tradition of fishing activities and concern for the fisheries resources of the Northwest Atlantic. In New England, as in Atlantic Canada, many of the groundfish stocks are presently depleted and undergoing a period of rebuilding. As a result, towns such as New Bedford, Gloucester, St. John's and Petty Harbour, along with many other communities in the Northwest Atlantic region have experienced much hardship. Consequently, what is at stake is not only a vision of sustainable harvest from the Northwest Atlantic, but also a way of life that is inseparably linked to the sea in countless coastal communities.

Although the United States is one of the newest members of the Northwest Atlantic Fisheries Organization (NAFO), the United States has always played a key role in the international conservation and management of Northwest Atlantic fisheries. These activities include work during the 1920s to establish statistical areas for the North Atlantic, convening of the 1948 international conference that led to the adoption of the International Convention for the Northwest Atlantic Fisheries and active membership in the International Commission for the Northwest Atlantic Fisheries (ICNAF). With the development of 200mile fisheries jurisdiction, ICNAF ceased to have relevance and the Convention on Future Multilateral Cooperation in the Northwest Atlantic Fisheries was adopted in 1978. Although the United States participated 
in the negotiation that established NAFO, it did not become a Contacting Party to the NAFO Convention until 1995. In the meantime, however, the United States attended NAFO Meetings as an observer.

This paper addresses the future of the international law of capture fisheries. Building on the 1982 United Nations Convention on the Law of the Sea, this paper will discuss how a new environmental awareness and a more specific articulation of legal responsibilities in international fisheries conservation and management are reflected by the recent adoption of the UN Fish Stocks Agreement and the Compliance Agreement. The paper will then discuss how these agreements illustrate a paradigm shift in international fisheries and will argue that fisheries organizations, like NAFO, must boldly apply the principles reflected in these agreements if they are to maintain sustainable fisheries and prevent fisheries management from increasingly being usurped by non-fisheries bodies.

It is especially appropriate to discuss the future of international fisheries law in the setting of NAFO because of the long history of international fisheries in the Northwest Atlantic. While other areas, such as the North Sea, have had similarly long histories of international fishing activity, fisheries in those areas have tended to be limited to the littoral nations of the area. The Northwest Atlantic Ocean is different. It is different because it has always involved both Coastal States and distant water fishing States. NAFO is also one of the few international fisheries organizations which has most of the great fishing nations as members. Thus, the Northwest Atlantic is a region where the implementation of international fisheries law is most dynamic, will face its greatest challenges and, hopefully will find ultimate success.

\section{Modern International Law of Fisheries}

\section{The 1982 United Nations Convention on the Law of the Sea}

Any discussion of the modern international law of fisheries must start with the 1982 United Nations Convention on the Law of the Sea. That treaty, among other things, drew a bright line in the oceans - the 200-mile line - that separates the high seas from waters under the exclusive fisheries jurisdiction of Coastal States. Inside their respective exclusive economic zones (EEZs), Coastal States have exclusive authority to conserve and manage fisheries, subject to general obligations to prevent overfishing and, where they exist, to allocate surplus fishery resources to other nations. Outside the EEZ of Coastal States, all nations have the right to fish, but this right is made subject to certain responsibilities and to general obligations to cooperate in the conservation and management of fishery resources. As reflected in the Law of the Sea Convention, 200-mile fisheries jurisdiction is a generally accepted feature of international law. That is no small accomplishment, for it has ended years of disputes about the legitimate extent of Coastal State fisheries jurisdiction.

Unfortunately, the general obligations regarding conservation and management of fisheries, as set forth in the Law of the Sea Convention, have not proved specific and comprehensive enough adequately to protect most fish stocks. Further articulation of rules and enforcement mechanisms is necessary to address the current crisis in marine fisheries, in which, as reported by the FAO, about $70 \%$ of the world's marine fisheries are in need of urgent attention.

The international community has responded to this crisis in a number of positive ways. Applying a new environmental awareness, which will be discussed in more detail later, fishing nations have begun to develop the necessary and more specific articulations of the international legal responsibilities flowing from the Law of the Sea Convention. At the 1992 Earth Summit in Rio de Janeiro, all nations joined in the call for new international agreements to achieve sustainable marine fisheries. In fact, such arrangements were concluded in the ensuing years. Those new instruments include the 1995 United Nations Agreement on Straddling Fish Stocks and Highly Migratory Fish Stocks (UN Fish Stocks Agreement), the FAO Code of Conduct for Responsible Fisheries, and the Agreement to Promote Compliance with International Conservation and Management Measures by Fishing Vessels on the High Seas (Compliance Agreement), which is part of the Code of Conduct. In addition, several new regional agreements have also been concluded, including one to govern the pollock fishery in the Central Bering Sea and another on anadromous stocks 
in the North Pacific Ocean. These are important agreements that set the specific rules the international community will need to apply to move toward sustainable marine fisheries. They are also important because they increasingly recognize environmental considerations and the importance of fisheries resources to the environment.

\section{The 1995 UN Fish Stocks Agreement}

The UN Fish Stocks Agreement builds upon the general fisheries rules of the Law of the Sea Convention as they relate to the conservation and management of straddling stocks and highly migratory stocks. As specified in Articles 63 and 64 of the Law of the Sea Convention, the Agreement recognizes that these fish stocks must be managed throughout their range. Article 63(2) of the Convention provides that for straddling stocks, the Coastal State and States fishing for such stocks on the high seas shall seek to agree upon the measures necessary for conservation on the high seas. Article 7 of the UN Fish Stocks Agreement implements this general obligation further by requiring that the conservation and management measures established for the high seas and those adopted for areas under national jurisdiction are to be compatible in order to ensure conservation and management of straddling fish stocks in their entirety. The Agreement then provides several factors that States are to take into account in fashioning compatible conservation and management measures. These factors include the conservation and management measures adopted by the Coastal State and those applicable on the high seas; other agreed measures established by regional organizations; biological, fisheries and geographic considerations; the dependence of the Coastal State and other fishing States on the stocks concerned; and the need to ensure that the measures do not result in harmful impacts on living marine resources as a whole.

The UN Fish Stocks Agreement also imposes strict requirements on States whose vessels fish on the high seas, and provides for more effective monitoring and enforcement of high seas fisheries. The Agreement calls upon both Coastal States and high seas fishing States to adopt the precautionary approach to fisheries management, both inside and outside the 200-mile line, and to collect and share data. It also calls for the creation of new regional fishery organizations to manage specific fisheries, and for specific improvements in the way existing regional fishery organizations operate. These organizations must improve their decision-making mechanisms, provide greater transparency, address difficult issues posed by new members and non-members, and resolve disputes promptly and effectively under procedures established in the Law of the Sea Convention. The tightening of enforcement regimes, particularly with regard to non-member fishing, represents an important step forward in enabling the international community to conserve fish stocks.

Although the UN Fish Stocks Agreement is not yet in force, its call for action has already spurred efforts to create new regional organizations for straddling fish stocks in the Southeast Atlantic and for highly migratory fish stocks in the Western and Central Pacific. Its call for the precautionary approach, transparency, dispute settlement, compliance and enforcement, and for efforts to deal with non-members are also providing the basis for international negotiations in NAFO and elsewhere. The United States views such developments positively, and fully supports the early implementation of key provisions of the UN Fish Stocks Agreement.

Two of the more challenging areas of change for regional organizations will be implementation of the precautionary approach and transparency. When the UN Fish Stocks Agreement enters into force, a legal requirement will exist for all its Parties to adopt the precautionary approach in their own fisheries management and in regional bodies. Based on the advice of scientists on appropriate reference points, it will be up to managers and decision-makers to make the precautionary approach a reality. The NAFO Scientific Council discussed the precautionary approach during its June 1997 Meeting and established an Ad hoc Working Group on this subject. The Scientific Council has proposed an Action Plan for implementing

1 The NAFO Scientific Council Workshop on "The Precautionary Approach to Fisheries Management", was held 17-27 March 1998, NAFO Headquarters, Dartmouth, Nova Scotia, Canada (NAFO, SCS Doc. No. 98/1, Serial No. 2987, 64 p.). 
the precautionary approach in the NAFO Regulatory Area and a special Scientific Council Workshop on the "Precautionary Approach to Fisheries Management" will be held in March $1998^{1}$. NAFO and its Contracting Parties should be commended for these efforts and should serve to encourage other international fisheries organizations and arrangements to do likewise.

Transparency, as called for in Article 12 of the UN Fish Stocks Agreement, will also create challenges for regional fisheries organizations like NAFO. The world is moving in the direction of providing greater transparency in all international organizations and meetings. It is important that the environmental community, fishing interests and the public at large be given the opportunity to understand the decision making process in regional organizations and to provide relevant information and advice. The United States recently circulated to all NAFO members proposed rules to grant observer status at NAFO meetings. We hope that NAFO will adopt new rules on transparency and implement them as soon as possible.

Ratification or accession by thirty States is required to bring the UN Fish Stocks Agreement into force. To date, 15 nations have deposited instruments of ratification. Among NAFO members, only Iceland, Norway, the Russian Federation and the United States have deposited instruments of ratification, although Canada, Japan, Korea and the European Community have signed the Agreement. The United States urges other NAFO Member States to ratify this important agreement which forms the basis for the future of sound fisheries conservation and management in organizations like NAFO.

\section{The 1993 Compliance Agreement}

The Compliance Agreement is another important element in the more specific articulation and application of the rules of international law to capture fisheries. This agreement, which was adopted in 1993, is an integral part of the Code of Conduct for Responsible Fisheries and is the only part of the Code that is legally binding. This Agreement also builds upon obligations found in the Law of the Sea Convention for States whose vessels fish on the high seas.

The Compliance Agreement's two primary objectives are: first, to impose upon all States whose vessels operate on the high seas an array of obligations designed to make the activities of those vessels consistent with conservation and management needs; and second, to increase the transparency of all high seas fishing operations through the collection and dissemination of data. These provisions establish a sound basis on which to conduct high seas fishing if living marine resources are to be properly conserved and managed. They are designed to combat two practices. One is the practice of reflagging to a country not a member of regional organizations as a means to avoid fishing restrictions placed on member States. The other is the growing practice of registering newly built high seas fishing vessels in States that are not members of the major multilateral fisheries organizations, precisely because these States are not bound by the restrictions adopted by those organizations. These provisions complement those of the UN Fish Stocks Agreement and the Code of Conduct, giving us the tools to tighten management and enforcement regimes.

The Compliance Agreement requires twenty-five instruments of acceptance to come into force. To date, only nine nations and the European Community have submitted instruments of acceptance. Again, we urge all nations, which have not done so to take action to bring this Agreement into force as soon as possible.

It is encouraging that the international community is already witnessing efforts to give effect to the UN Fish Stocks Agreement and the Compliance Agreement even before their formal entry into force. For example, the United States and other nations are engaged in efforts to combat fishing activities by countries that are not members of the appropriate regional fisheries organization. In the Atlantic, concern over the extent and manner of fishing by non-members on heavily stressed bluefin tuna and swordfish stocks led the International Commission for the Conservation of Atlantic Tunas (ICCAT) to adopt the Bluefin Tuna Action Plan and the Swordfish Action Plan. In general, these plans provide the means for multilateral trade measures to be imposed on non-members conducting harmful fishing practices. In fact, the Bluefin Tuna Action Plan has been put into practice and has resulted in the adoption by ICCAT of a 
measure requiring its members to impose trade measures against three nations determined to have vessels fishing in a manner that diminishes the effectiveness of ICCAT conservation measures for bluefin tuna. This type of measure can also help resolve similar problems in other regional organizations. In NAFO, the Standing Committee on Fishing Practices of Non-Contracting Parties in the Regulatory Area (STACFAC) is also making excellent progress on developing a scheme tailored to the specific circumstances of $\mathrm{NAFO}^{2}$.

\section{The Paradigm Shift in International Fisheries Law}

The UN Fish Stocks Agreement, the Compliance Agreement and the Code of Conduct for Responsible Fisheries contain a number of provisions referencing broader environmental goals. These broader goals include the need for consideration of aquatic ecosystems, the need for an ecosystem approach to management, and the need to minimize by-catch, pollution, waste and discards. As such, they illustrate a "paradigm shift" in international fisheries, which flows from the increasing nexus between international fisheries law and international environmental law.

This paradigm shift involves growing recognition of two requirements for the sustainable conservation and management of capture fisheries. The first reflects ecosystem concerns. There must be effective steps to provide for the health, not only of populations of target species, but also of non-target species, and we must take steps to maintain relationships among species. Second, there must be effective steps to protect fisheries habitat. In particular, we must protect fisheries habitat threatened by adverse impacts stemming from human activities, including harmful fishing practices, and other activities, which are increasingly concentrated in coastal areas. In effect, fisheries managers must concern themselves with the entire marine ecosystem.

The second part of the paradigm shift, the need to protect fisheries habitat, gives rise to yet another set of concerns. The international community must ensure that efforts to manage fisheries, within the new ecosystem perspective, are matched by efforts to protect coastal estuaries and the marine habitats upon which fish populations depend for spawning and growth. Here the challenge rests with governments of Coastal States. Such governments must integrate fishery management policy with water quality protection efforts. Developing integrated strategies to maintain healthy fish populations and protecting marine habitat at the international level requires us to develop and take coordinated approaches on habitat related issues within regional fishery management organizations and the other relevant international bodies. This requires something that governments often have difficulty accomplishing - that is, taking consistent and integrated positions within different international institutions. Thus representatives in regional fishery organizations need to be advocates as well as practitioners of such an integrated approach.

Looking to the future, the United States believes that the time has come for fisheries managers and others involved in the development and implementation of international fisheries law to recognize and respond effectively to this paradigm shift. Today, the international community must recognize that the future of fish as an important source of food is inextricably linked to healthy marine ecosystems and unpolluted coastal waters.

What is being expressed here does not represent a change in the United States policy with respect to the management of international fisheries resources. The United States continues to believe that international fisheries resources must be managed and conserved in accordance with the obligations of Law of the Sea Convention and other fisheries agreements, through the appropriate regional organizations, and in close collaboration with the FAO. What needs to change is how the international community approaches the implementation of these obligations.

\footnotetext{
2 At its $19^{\text {th }}$ Annual Meeting in September 1997, the General Council of NAFO adopted the Scheme to Promote Compliance by Non-Contracting Party vessels with the Conservation and Enforcement Measures established by NAFO.
} 


\section{Creeping Fisheries Management: Addressing International Fisheries Issues into Other Fora}

Up to now, conservation and management decisions within multinational fisheries organizations have been guided by a body of international law which has had as its focus traditional capture fisheries concerns. In recent years, however, there has been increased involvement in international fisheries issues by other organizations concerned with environmental, wildlife trade and other issues. While scholars may be best able to explain this phenomenon, here it is argued that this involvement is linked not only to the full or over-exploited status of so many of the world's fisheries resources, but also to the paradigm shift mentioned earlier.

The United States believes that there is no reason to exclude appropriate consideration of marine fisheries issues in other international bodies or mechanisms, such as the Conference of Parties to the Convention on Biological Diversity (CBD), the Conference of Parties to the Convention on the International Trade of Endangered Species of Flora and Fauna (CITES), or the Commission on Sustainable Development (CSD), provided that they have competence and/or responsibilities for the marine environment. However, we also recognize that these other organizations do not have direct fisheries management and conservation authority for marine fish species. The task that faces fisheries managers and government representatives to regional fisheries bodies is to ensure that the resources and knowledge of such other organizations are harnessed to reinforce the work of the FAO and the appropriate regional fisheries organizations charged with the conservation and management of marine fish species. Without such integration, the efforts in these other organizations may be counterproductive to the efforts undertaken by FAO and to the conservation and management measures adopted by the relevant fisheries management bodies.

These other organizations can help support regional fisheries organizations in ensuring that management decisions are based on the best available science. This science should be a product of the appropriate regional body, if any. But it can and should be informed by the work of other organizations. If accomplished in a consistent and supportive manner, involvement in international marine fishery resources by these other bodies can be mutually beneficial, and can have a positive effect on the sustainable use, conservation and management of marine fish stocks.

It should be recognized that other organizations have often become involved in international marine fishery conservation and management because of a perception that regional fisheries bodies have been slow to incorporate an ecosystem perspective in their work. This corresponds to the first part of the paradigm shift mentioned earlier. Examples of such problem areas include by-catch of seabirds, sea turtles, marine mammals and other living marine resources, the conservation and management of sharks, and over-capacity. These and other problems will not go away. In fact, they are becoming more serious. To remain relevant into the next century, regional fisheries organizations must address these problems effectively and head-on.

The FAO Committee on Fisheries has taken up many critical fisheries issues that reflect ecosystem concerns. Work is underway for a three-part FAO Consultation in late-1988 to develop draft global plans of action for the conservation and management of sharks, management of fishing capacity, and the reduction of incidental seabird mortality in longline fisheries. The United States is pleased that the FAO Committee on Fisheries has taken up these issues and we believe these consultations will mark a new era in international fisheries management.

\section{Dealing with the Paradigm Shift in Fisheries Organizations and Arrangements}

Addressing within regional fisheries bodies the challenges presented by the paradigm shift will not be easy. Efforts to address these new issues will, no doubt, press on annual agendas that are already full. Addressing these new issues will also complicate what are already difficult management decisions. However, what are the alternatives? The alternative may be to manage fisheries through trade mechanisms or 
other mechanisms that are indirect rather than directly related to fisheries management. Bold action is needed to keep fisheries management where it should be - in fisheries organizations. If the international fisheries community fails through lack of cooperation to deal with these new emerging issues within regional fisheries bodies, the resulting vacuum will invite non-fisheries organizations to seize the initiative. The United States believes that regional fisheries organizations, like NAFO, are capable of evolving to meet the challenges of the next century, and we look forward to working with the other members of NAFO to this end.

\section{Conclusions}

In closing, as we approach the twenty-first century, some might wonder if we are approaching the twilight of traditional capture fisheries. I do not think so. Many challenges lie ahead, but if we eagerly accept them, we will find ourselves on the verge of a new era in capture fisheries.

Like the ocean itself, international fisheries law is dynamic, and it will evolve, as future needs dictate. As long as fish swim in the sea there will be a need for international fisheries law. But we have to accept that the future of international fisheries law must see beyond fish as simply a capture resource, and we must respond accordingly. We have the tools to do the job right. Now it is up to the international community to apply our leadership and make the vision of sustainable harvest from the Northwest Atlantic and throughout the world a reality.

Finally, in Twenty Thousand Leagues under the Sea, the undersea odyssey of the Nautilus takes it through the Grand Banks and the cod fishing grounds off Newfoundland. We are told that only through skillful steering was the Nautilus able to navigate through a vast network of fishing lines. In charting the future course of international fisheries conservation and management, it is my hope that we are skillfully guided by wisdom and courage, and that we set our course based not by the wake we leave behind, but on the challenges and the promise of the century which lies ahead. 
